\title{
Using a Tab Review Ms Word Semantic Mapping to Write a Text
}

\author{
Martha Maspaitella* \\ Faculty of Teacher Training and Educational Sciences, Universitas Pattimura, Ambon, Indonesia
}

\begin{abstract}
A RT I C LE INFO
Keyword:

digital writing

semantic mapping

Tab Review MS Word

A B S T R A C T

Writing is often perceived as a complicated activity since it requires the writer to read and organize sentences at the same time. Therefore, someone has to go through a certain process and apply appropriate strategies in order to be able to write. One of the strategies that can be applied to improve an individual's writing ability is semantic mapping using Tab Review MS Word. This strategy can be used to guide students, in this case, to write on a digital medium such as on the computer. By reading a particular text, students are able to determine a keyword together with its definition, make a semantic mapping, decide a topic, create a writing framework, and develop it into a piece of writing. Finally, writing is no longer a complex process, but a fun activity as the students' motivation has increased.
\end{abstract}

\section{INTRODUCTION}

Students often consider writing to be a complicated process since it requires them to show not only their reading ability but also their capacity to analyze, evaluate, and synthesize a text. Besides, many students also think that only the talented ones can write. In fact, there are two common difficulties faced by students in writing, that our attitude and knowledge (Mitchell, Thompson, and Anderson, 2017). Students who have abundant knowledge about writing but are not really into it may be unable to write well, or vice versa. In other words, knowledge and attitude work side by side on writing. Knowledge of writing should be relevant to writing attitudes. Otherwise, no one can produce a piece of writing which carries a certain purpose and context. Instead, writers should deal with plagiarism issues.

Plagiarism is a realization of student writers' inability to understand texts. It is very difficult for the students to generate new ideas because they are unable to analyze, and synthesize the texts (Horning, 2012:22). In addition to that, students' positive and negative writing experiences should be taken into account. Teacher as a facilitator needs to encourage the student writers to find a joy in writing. The teacher can teach the students skills and attitudes to work together with other students, do writing assignments, and solve problems (Robertson, Patterson, \& Wickstrom, 2017:247-250; Browning, 2012:143).

The teacher can also help students understand the purpose of writing. Student writers have to ask themselves and ask their friends about how to effectively overcome writing problems (Robertson, Patterson, \& Wickstrom, 2017:249; Olmanson, et al. 2007:103; Bailey, 2015:3). The students may be able to produce an academic writing in an instant. However, a good piece of writing can only be generated through a process which covers some stages namely planning, monitoring, drafting, revising, and editing (Ortlieb, et al., 2017:2-5; Du, et al., 2016:382; Kurniawan, 2015:49; Nurudin, 2012:74; Bazerman, et al., 2005:58). Every writer has to go through this process in order to be an effective writer. An effective writer can later improve his/her creativity further if s/he wants to be a professional one.

This article was written based on an adopted theory suggested by Olmanson in "Visualizing Revision: Leveraging Student-Generated Between Draft Diagramming Data in Support of Academic Writing" which discusses semantic mapping. Semantic mapping in Olmanson's article was originally used to revise a composition, but this article focuses on discussing the use of the semantic mapping and tab review Ms. Word in generating a piece of writing.

Writing, in this paper, is defined as a process of integrating knowledge into a social context. The integration of knowledge to the social context is realized through a reading activity and information sharing. Student writers need to

\footnotetext{
${ }^{*}$ Corresponding author.

E-mail addresses: martha.maspaitella@fkip.unpatti.ac.id (Martha Maspaitella)
} 
read various literature to enrich their knowledge. They also need to discuss with their friends and teacher to clarify obtained information before they start to write and create a writing framework from a semantic mapping and then develop it into a composition.

By following these stages, the student writers may be able to deal with some barriers to writing such as low interest in writing, linguistic block, and lack of ideas. The students can also collaborate with the teacher and other students in writing. The students may ask for help and suggestion from them and take it into consideration to revise their writing pieces (Robertson, Patterson, \& Wickstrom, 2017:248; Bailey, 2015:3; Olmanson, et al., 2007:103). In Horning (2012:36), Tierney points out that learners need to become (1) a creative and effective information and technology user, (2) an information seeker, an analyst, and an assessor, (3) a decision maker and a problem solver, (4) a communicator, a collaborator, a publisher, and a producer, and at last (5) a responsible citizen (Tierney, 2009: 293).

Another reason why semantic mapping can help students write is that because it assists the students in organizing their thoughts, structuring their language, and integrating their reading and writing ability. Since writing requires the students to rearrange their cognitive, epistemic, affective, and linguistic identity, it should be approached by language organization (Blommaert, 2004:645).

The writing process addressed in this paper falls into the digital writing category. This process begins with reading some related texts and is followed by determining which parts of the texts should be included in the writing. After that, the writers may share the information with their friends, interpret some related literature, and arrange the semantic mapping from the most general ideas to the most specific ones.

Wu (2013:13-15) believes that writing can improve the writer's knowledge, social interaction, and communication ability. Through writing, someone can enrich his/her knowledge and improve his/herself in applying the knowledge into a social process and context.

Writing also constitutes a complete interaction process between some components which influence each other. These components include academic vocabulary, sentence patterns, academic functions, academic text types, and curriculum context. The harmony created among the components supports the writing process (Lin, 2016:38). The harmonious pattern of these various components is depicted in the following figure.

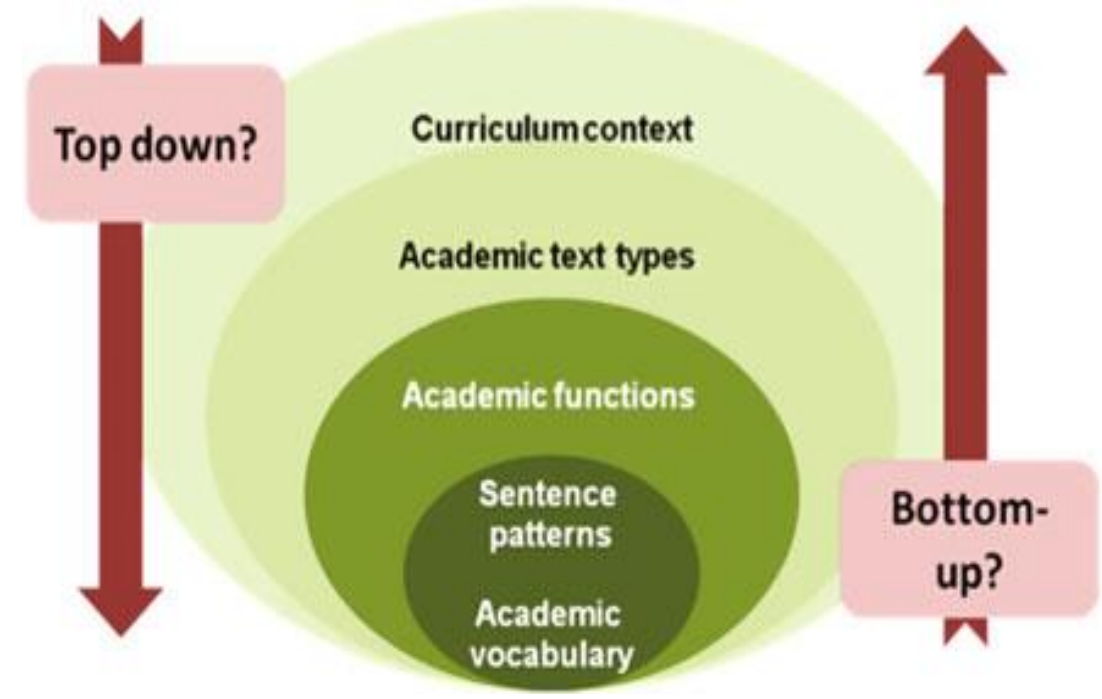

\section{DISCUSSION}

Figure 1. The components of the harmonious pattern

\section{Digital Writing Learning Model}

The famous $21^{\text {st }}$-century digital era intends to teach students to be a more effective writer on the online and offline digital media. Online media refer to the telecommunication and multimedia-based media (computer and the internet). These media provide a social and interactive platform to encourage students to write. Meanwhile, offline media are defined as media provided by the computer only with no internet connection. Both media are accessible to the students. These media provide students with learning materials in the forms of texts, photographs, videos, and audio files.

Digital or electronic learning model is also called E-learning. Another form of this learning model is blended learning which combines online, offline media with classroom conventional methods. Blended learning makes it possible to accommodate a face-to-face learning in a computer, cellphone, satellite television, or video conference.

This learning model apparently can motivate students in writing, and building a communication between teacher and students. The teacher can create a digital forum as a classroom so that learning can occur both inside and outside the physical classroom. Digital media provide an opportunity for the students to do their tasks from everywhere and at any time. The students can also collaborate with the teacher and other students to revise and edit their writing. This multimodal learning environment is able to motivate the students to write because it offers them a more meaningful learning experience through which they develop their writing habit. Images, videos, electronic books, and other digital texts contained in the digital media may inspire the students to keep writing (Darrington and Dousay, 2015). 
The teacher can provide a feedback to students' writing. S/he also needs to write a manual which can guide the students in arranging, revising, and editing their composition before it is published or posted. Learning can be conducted classical, individual, or in a small group. The focus of learning should be put on applying appropriate writing strategies to improve the quality of the students' writing.

There are nine principles of teaching writing suggested by Bazerman (2005:52). These nine principles include (1) adjusting learning method to high achievers' standard of writing and thinking, (2) using procedures to deliver procedural knowledge, (3) determining a clear objective of writing an informal and unprocessed writing, (4) making a peer assessment sheet, (5) creating a teacher' s responses sheet based on the writing and reward system, (6) generating students worksheets carefully, (7) providing an explicit instruction, especially when deciding a peer audience and familiar topic or setting for the students, (8) offering basic guidance, (9) using language which is comfortable both for the teacher and the students.

Digital media learning model to teach writing can be various such as learning to write through offline computer, blog, wikis, mobile, ubiquitous, email, mailing list (milis), website, WhatsApp, social media, and other online platforms or links (Ortlieb, et al. 2017; Mitchell, Thompson, and Anderson, 2017; Du, Helen S. 2016; Sanchez, Soraya Garcia and Carmen Lujan-Garcia. 2015; Kanala, Nousiainen, and Kankaanranta, 2013).

The digital platforms of links that can be utilized by the students to write are (a) YouTube and Brain POP videos to have an online discussion and write a draft, (b) Kidspiration to help organize thoughts before writing a draft, (c) Google Docs to help draft a composition, revise, and edit it, (d) Kidblog to help provide feedback to the draft, (e) WikiSpaces as a link to help teacher provides examples, and (f) StoryJumper Prezi, and Windows Movie Maker to publish the composition (Mitchell, Thompson, and Anderson, 2017).

\section{Texts Used as A Medium to Write}

Texts are written in various ways with different communicative purposes and contexts. It means that when a writer wants to produce a piece of writing, s/he will consider using a language which can help her/him communicate the meaning in a certain context and with a particular purpose. Continuously, the writer will make distinguished language choices, such as lexico-grammatical, and rapho-phonological options, when writing different genres.

Three important aspects that also need to be taken into consideration in writing are field, tenor, and mode. The field covers what is written, and to what field of information the writing can contribute to. Tenor comprises a consideration of targeted readers. Mode explains channels or media used by the writers to publish their composition. Therefore, texts are constructed and built in many different ways according to their genre (purpose), and register (field, tenor, mode) (Lin, 2016:15-19).

If applied to learning, writing refers to a process of connecting and linking written and oral competence (Robertson, Patterson, \& Wickstrom, 2017). A composition produced can be in the form of local/low social distance, global/high social distance, specialized discourses, and everyday discourses. All constructed discourse have to contain field, tenor, and mode. The language variation framework is presented in the following figure.

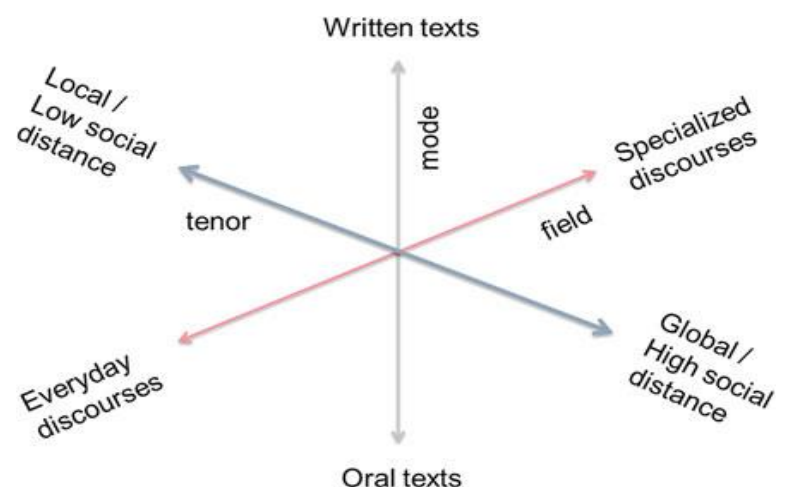

Figure 2. Language Variation Framework for Education

Therefore, besides serving as a medium to communicate texts, language can also be categorized into texts in social contexts which cover grapho-phonics, lexico-grammar, discourse semantics, register, and genre. Furthermore, language can also help us to read to write, read to speak and write to speak.

According to Horning (2012:21), texts in particular involve elements such as (1) relationship, which refers to an interaction between ideas or characters in a text, (2) richness, which means that texts contain a large amount of information and are delivered through data or devices, (3) structure, which means that texts sometimes have a complicated organization and sometimes unconventional, (4) style, which refers to writer's tone and language use, (5) vocabulary; writer's choice of words highly depends on the contexts, and (6) writer's purpose, which is sometimes implicitly stated and ambiguous.

Texts in the digital writing context consist of environmental texts, videos, images, audio files, narratives, expositions, or persuasive texts (Mitchell, Thompson, and Anderson, 2017; Neumann, Finger, and Neumann, 2016). According to Bazerman (2005:45), text types, in general, can be categorized as follows. 


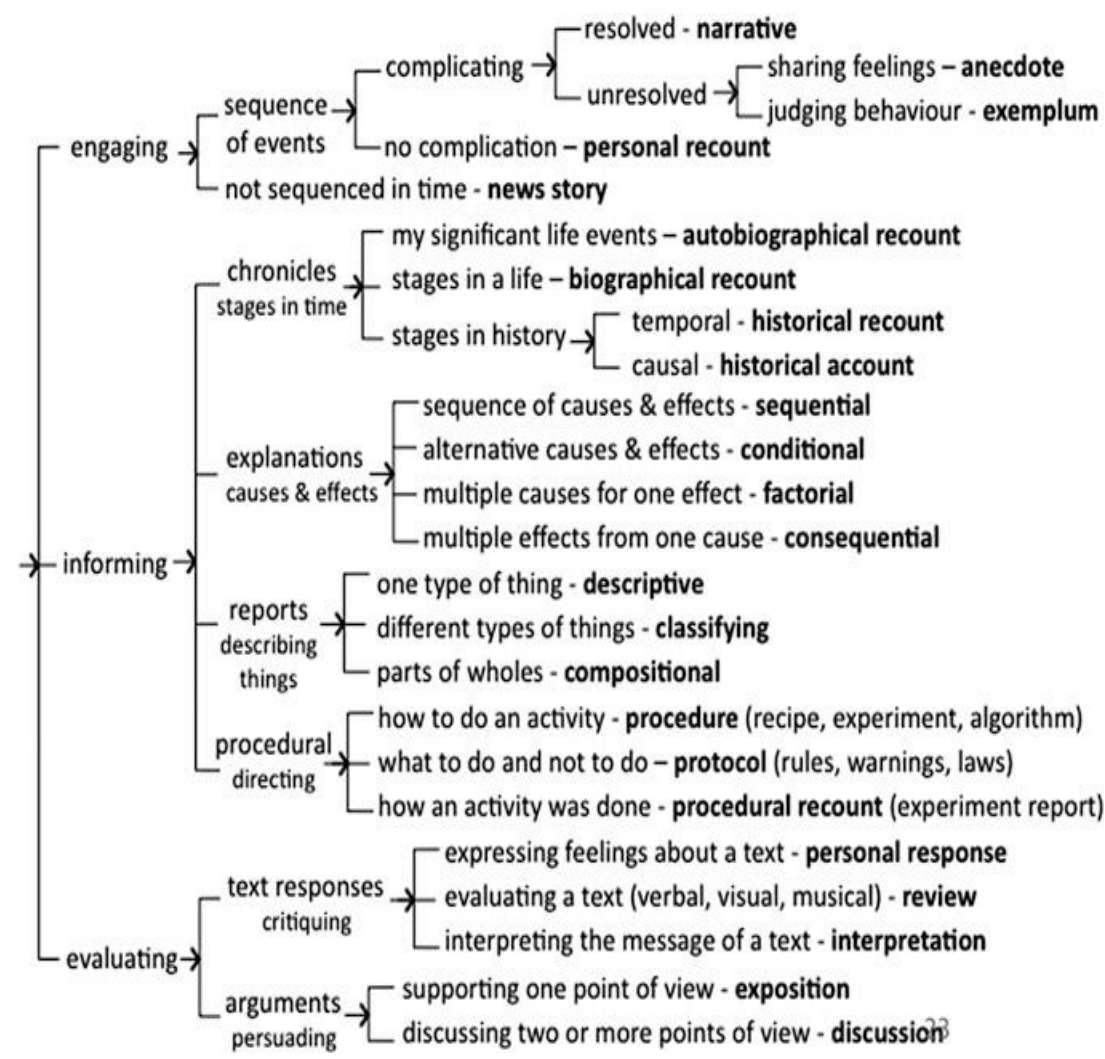

Figure 3. Text Types in general

Writing as a product covers all text types suggested by Bazerman in Figure 3. However, text types produced by students should be adjusted to the learning materials, students' learning experiences, and students' ability to use written the language (Robertson, Patterson, \& Wickstrom, 2017).

Britton in Bazerman (2005:57) categorizes functional writing into three groups. The first group is the transactional writing of which purpose is to communicate or to inform. Another group is poetry which contains beauty and the other group is the expressive writing which aims to explore or contemplate an idea. The latest should be considered the most important for the university students if they want to learn how to write or produce a writing product. Writing tasks include academic essays, research reports, reviews, literature review, summaries, and critical analyses of texts, notes, summaries, or papers (Bailey, 2015:4; Paltridge, 2004:84).

\section{Tab Review Ms. Word}

Microsoft Office Word (MS. Word) is a word processor invented by Microsoft Corporation. One of the MS Word features which serve to manage functions or change the template is Tab Review.

Icons on Tab Review, according to Murbarani (2013), fall into some categories. The first group is proofing. It consists of (1) icon spelling, which is used to check the spelling, (2) icon research, which is used to open research task pane to search references, such as dictionary, encyclopedia, and translation tool, (3) icon thesaurus, which provides suggestions of word synonyms or antonyms, (4) icon translate, which is used to translate a word in a source language into a target language, (5) icon language, which is used to organize language used in a text and check its spelling and grammar.

The second category is commented. This category contains (1) icon show markup, which shows comments, explanations, or other important notes, (2) icon new comment, which is used to add more comments to what has been selected or pointed, (3) icon edit comment, which is used to edit previous comments, (4) icon delete comment, which is used to delete comments, (5) icon previous comment, which is used to direct to the previous comments attached on that document, (6) icon next comment, which is used to direct to the next comments attached on that document.

The third category is the protection. Icons found in this category are icon protect presentation, which is used to limit the access to the presentation slides (unlimited, limited, and credential access). The following figure presents Tab Review together with its icon groups. 


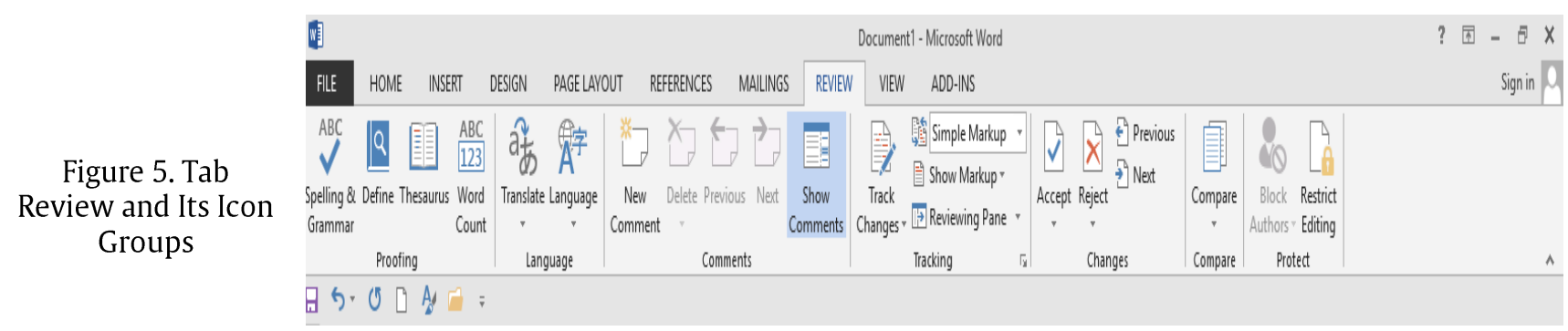

\section{Semantic Mapping Strategy Using Tab Review Ms. Word}

Concept mapping was introduced in the early 1970s by Joseph Novak and his partners. Since then, it has been adopted as a learning tool by teachers and students. Concept mapping is mostly used by teachers to plan concepts related to learning materials, meanwhile, students employ concept mapping in organizing their knowledge, starting from identifying concepts to generating a concept map.

Concept mapping has a 'hierarchical tree' structure composed of super-ordinates (general), subordinates (specific), and links between concepts (Li, 2015:2012; Chu, Hwang, \& Liang, 2014:19-21; Rye, Landenberger, \& Warner, 2013:380). Concept mapping also refers to a structure conceptualization which can be used to develop a conceptual framework for an evaluation, practice, and etc. (Marín, et al., 2006:240).

Concept mapping also constitutes a concrete graphic illustration which helps identify links between a single concept and other concepts in the same category (Trianto, 2007:159). This concept mapping is aimed to help students build an external, graphics, and representative link between spatial concepts which are drawn in a circle, triangles. This activity reflects students' strong representation of their knowledge.

Concept mapping is hierarchically structured. More inclusive concepts will be put on the top, and the less inclusive ones will be sorted below them. The characteristics of concept mapping suggested by Dahar in Trianto (2007:159) include:

1. Concept mapping is a way of clarifying a subject by showing the links between concepts and proposition.

2. Concept mapping presents a two-dimension image of the whole or a part of a subject.

3. Each concept has its own quality.

4. If two or more concepts are drawn below a more inclusive concept, a hierarchy can be built on the map.

\section{Semantic Mapping Strategy}

Semantic mapping strategy is a strategy used to determine keywords of a text, and then explain the meaning through Tab Review in MS Word. Those word definitions are mapped by outlining ideas that are going to be developed into a composition. Before generating the map, keywords must be described as a semantic concept.

In relation to meaning, Cruse (2004: 262) introduces dynamic construal approach as to explain that words definitions are not permanent. Words will be meaningful when they are used in a certain context (language use). However, this rule does not fully apply to terms. The Linguistic Dictionary (Kridalaksana, 2009: 97) defines terms as words or phrases that carefully reveal concepts, processes, circumstances, or distinguishing features in a particular field. Since terms are only used in a certain domain, their definitions are therefore restricted. Keywords in this paper refer to scientific terms that can be found in the students' writing. The contexts of the keywords are articles related to the text.

Cruse (2004: 176) divides relation in a hierarchy in relation to dominance and relation of differentiation. In a tree diagram, the relation of dominance is pictured in a horizontal (top to bottom) link, meanwhile, the relation of differentiation is marked by a linear link linear (right to left). Structurally, a relation which is constructed as a linear link is called syntagmatic, and the relation which is built as a horizontal link is called paradigmatic.

Semantic mapping is made by students to describe a concept using words, phrases, or sentences, and provide statements and facts that can define the concept. In addition to that, students use semantic mapping to accommodate data using statistic to describe more than one concepts, quote someone's words from a book, speech, interview, poem, drama to help explain a concept or perspective, then draw a conclusion on why that work has been created to present this information, including communicating the importance of the topic, ask questions about it, see through the future, and evaluate personal or public comments on it. Those concepts are mapped in a tree diagram or a network tree, chain, cycle, or spider web (Olmanson, 2007:102-103; Trianto, 2007:161-165).

\section{Syntax of Semantic Mapping Using Icon Review MS Word}

A semantic map is generated through four common stages including (1) identifying keywords or main concepts that cover a number of concepts, (2) identifying secondary concepts which support the main concepts, (3) placing the main concepts in the middle or on top of the map, (4) putting the secondary concepts around the main concepts visually or horizontally to show the connection between those concepts. The stages of generating a semantic map using Tab Review MS Word are described as follows.

1. Students are divided into heterogeneous groups; 
2. Teacher delivers key points of the learning materials and work procedures that should be followed by each group;

3. Students determine related keywords, phrases, and sentences from the reading texts;

4. Students read a dictionary and related literature to explain the selected keywords;

5. Students define the keywords using icons of Review MS Word

6. Students organize the keywords based on the hierarchy of the concept map model (either a tree diagram or network tree, chain of events, cycle, or spider web)

7. Students make a concept map from the defined keywords;

8. Students generate a writing framework as an individual task from the semantic map;

9. Students develop the framework into a full text;

10. Students submit their work be revised by the teacher and their peers;

11. Teacher uses icons of review MS Word to visualize the results of the revision;

12. Students revise their writing and resubmit it to the teacher.

Figure 6 and 7 respectively present an example of defining keywords and semantic mapping

\section{PENERTAHANAN BAHASA DAERAH \\ MELALU PENGGUNAAN BAHASA DAERAH DALAVI KARYA SASTRA}

(Sumber: http://badanbahasasakemdilibudd.go.id lamanbahasad artikel/1286)

Bahasa merupakan alat utama bagi pengarang untuk mengelspresikan pengamatannya terhadap kehidupan dalam bentul karya seni (sastra). Ragam bahasa yang digunakan pengarang itu memerlukan proses parajugn. Untuk. merealisasilan gagasan, pikiran, dan perasaannya bahasa diolah dann disajikannya sedemikian nopa meladui proses kreatif hingega tercipta karya sastra yang imajinatif dengan unaur estetis yang dominann. Ragam bahasa dalam karya asstra tidald dapat disamakan dengan ragam bahassa nonkarya sastra, seperti bahasa dalam karya ilmiah, surat kabar, atau perundangoundanggan. Ragam bahasa dalam karya sastra

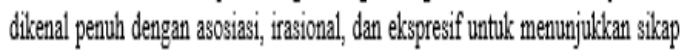
pengarangunya sehingga menimbullan efek tetentu bagi pembaca, seperti memengaruhi, membujuk, dan mengubah silkap pembacanya (Wellex. dan Warren, 1990:15).

Begitu pentingunya bahasa dalam proses kreatif Damono (1980:57) mengatakan bahiwa sastra addalah dunia kata. Atrinya, tokoh cerita ditampillan melalui kata, peristiwa teranglkai dengan kata, waktu dan tempat terjadinya juga oleh kata. Sebutan kata, memurot Damono, dapat dimaknail bahassa meskipun kata merupakan unsur bahasa. pula, Lotman (dalam Teeurv, 1984:99) jugga mengatakan, karena pentinganya peranan bahasa, ia menyebut bahasa sebagga tanda primer. Sebagai tanda primer, bahasa membentuk model dunia bagi penggunanya, yaitu sebagai model yang digunatan untuk menafisitan segala sesvatu, baik dari dalam mavpun dari luar dirinya.

Penggunazan kosakata bahasas daerah dalam karya sastra Indonesia modern bukan merupakan hal yang baru. Bahasa daerah telah lama digunakan oleh banyak. pengarang Indonesia, baik dalam karya fiksi mavpun puisi. Ada pengarang yang hanya menyelipkan beberapa kosakata bahasa daerah dalam karyanya, tetapi ada juga yang secara sadar menggunakan kosakata bahasa daerah untuk menarik p deo

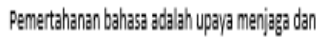
melestrikan bahas dri situsi pergegeran bah hasa attu kepunashan.

9 deo

Bahass deserah adal ah bahass selain bohass Indonesia dan bahasa asing. Bahlass daerah mervpakan bahasa yang dipargunakan penduduk asi suatu daerah (Kridalkssan, 2008:25)

deo 41 minutes ago

Bahasa sdalah sistem lambang buryi yang dipergunakan oleh para anggota guatu masyarakat untruk bekerja sama, berinteraksi, in mengidentifiksosikan diri (Kridalaksans, 2008.24) Hakikat bahass meliputi konsep tentang bahase sebogai unitan buny gampai pada housegp bahasa sabagad gegala sesuatu yang dapat dibicarakan, temsovk alat yang digunakan untuk membicarakanya. Teori bahesa dapat didasarikan pada asumsi babiva bahasa sebenamya adalah (1) substanci, (2) beantik, atau (3) bentuk dan grostansi. Hal ini sependapat dengan Kaelan (1998:263), yang menyebutkan bahntra substansi bahassa dibedackan antara (1) substansi bahasas sebagai gistem tanda, dan (2) grostansi bahasa yane menupakan acuan dari bahasa yang merupakan petanda

M deo Ragam bahnasa disebut juga variasi bahasa. Timbulnva ragam bahasa disebabkan oleh latar belakang 505ial, budaya, pendidikan, dan bahassa para pemakainya itu (Kurniawann, 2015:13).

Q deo

Kreatif ada ah memiliki daya cipta atou kemampun untuk menciptakan sesuatu (KB8B, 2008:739)

M deo Sastra menurut Lkens (2003:9) adal Ih kar)a yang

Figure 6. Defining Keywords Using Tab Review MS Word 


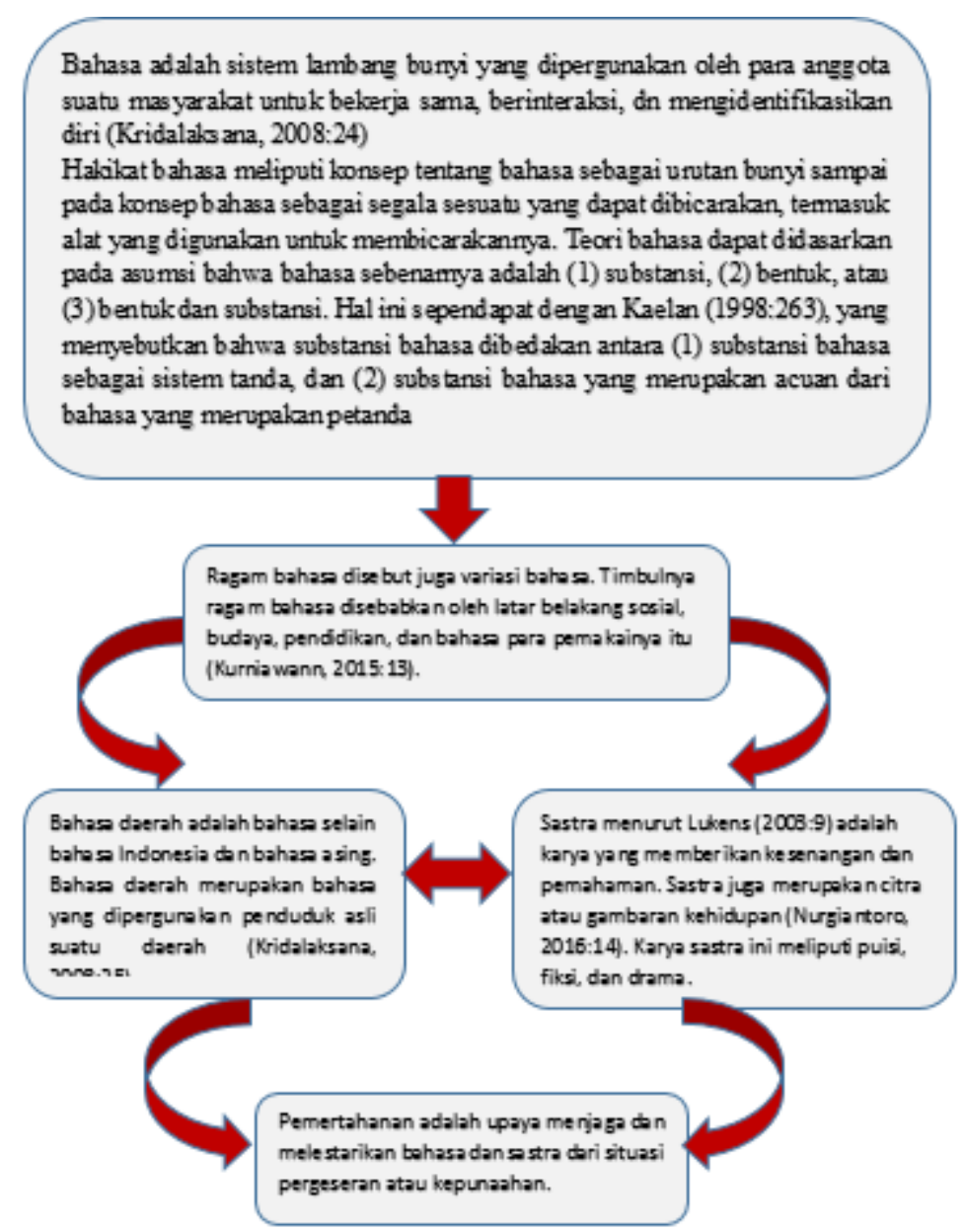

Figure 7. Semantic Mapping

\section{The Implementation of Semantic Mapping in Writing}

In general, the semantic mapping can be implemented at the pre, whilst, and post writing stages. The stages can be explained as follows.

1. Identifying students' difficulties in writing based on the composition that has been made;

2. Deciding learning objectives;

3. Making a writing lesson plan based on the results of students' difficulties identification;

4. Selecting relevant texts as well as media which should be read and mapped;

5. Presenting the materials

6. Providing stimulus and scaffolding;

7. Implementing the semantic mapping strategy;

8. Deciding an appropriate assessment tool and follow up to the implementation

\section{CLOSING REMARKS}

The semantic mapping strategy does not only offer a concept to be applied in a writing lesson. It also serves as a standard to which teacher can refer to in order to find out students' knowledge and difficulties in writing. Students' writing ability and level of understanding can be reflected in their composition which is constructed using a semantic map.

The key to applying this strategy is to integrate reading and writing. The collaborative and humanist process can occur in learning because students are given an opportunity to work together on their semantic map although later they need to write a text from it individually. As a result, students' achievement can be assessed from the cognitive and affective domain. Besides, semantic mapping also helps students avoid plagiarism.

\section{REFERENCES}

Bailey, Stephen. (2015). Academic Writing. A Handbook for International Student. Fourth Editon. New York: Routledge Bazerman, Charles, et al. (2005). Reference Guide to Writing Across the Curriculum. Indiana: Parlor Press. 
Blommaert, Jan. 2004. Writing as a Problem: African Grassroots Writing,

Economies of Literay, and Globalization. Language in Society 33, 643-671.

Browning, Randi. 2012. Blending Collaboration and Competition: A Model for Small Group Learning in Business Writing Classes. Hunter, in Kathleen M. (Ed) Collaborative Learning and Writing. Essays on Using Small Groups in Teaching English and Composition. North Carolina: McFarland \& Company.

Chu, Hui Chun, Gwo-Jen Hwang, dan Yi-Rong Liang. (2014). A Cooperative Computerized Concept-Mapping Approach to Improving Students' Learning Performance in Web-Based Information-Seeking Activities. J. Comput. Educ. 1 (1), 19-33

Cruse, Alan D. (2004). Meaning in Language: An Introduction to Semantics and Pragmatics. Oxford: Oxford University Press.

Darrington, Brett dan Tonia Dousay. (2015). Using Multimodal Writing to Motivate Struggling Students to Write, in Association for Educational Communications and Technology, Vol. 59 (6), 29-35.

Du, Helen S. (2016). Collaborative Writing With Wikis: an Empirical Investigation. Online Information Review, 40 (3), $380-399$.

Horning, Alice S. (2012). Writing, Reading, Digitizing. Understanding Literacy in The Electronic Age. Newcastle: Cambridge Scholars.

Hunzer, Kathleen M. (2011). Collaborative Learning and Writing. Essays on Using Small Groups in Teaching English and Composition. Amerika: Shutterstock.

Hyland, Ken. (2008). Genre and Academic Writing in The Disciplines. Language $\quad$ Teaching. Vol. 41 (04), 543-562.

Johnson, Christopher W. (2017). A Framework for Literacy: A Teacher_Researcher Partnership Considers The "C-S-C Paragraph" and Literacy Outcomes In Writing Instruction to Support Literacy Success. Literacy Research, Practice, and Evaluation, Vol. 7, 221240.

Kanala, Sari, Tuula Nousiainen, dan Marja Kankaanranta.(2013). Using a Mobile Motivation, in Interactive Technology, and Smart Education, Vol. 10 (1), 4-14.

Kurniawan, Khaerudin.(2015). Bahasa Indonesia Keilmuan untuk Perguruan Tinggi. Bandung: Refika Aditama.

Li, Liang Yi. (2015). Development and Evaluation of a WEB-Based e-Book With a Concept Mapping System. J. Comput. Educ, 2 (2), 211 226.

Lin, Angel M. Y. (2016). Language Across The Curriculum \& CLIL in English as an Additional Language (EAL) Contexts. Theory and Practice. Singapore: Springer.

Mitchell, Jessica S, Rachael F. Thompson, dan Rebecca S. Anderson. (2017). Understanding a Digital Writing Cycle: Barriers, Bridges, and Outcomes in Two Second-Grade Classrooms, in Literacy Research, Practice and Evaluation, Vol. 7, 137-155.

Murbarani, Dwinita. (2013). TIK Fungsi View dan Review (PowerPoint). https://www.slideshare.net/dwinitanakajima/tik-fungsi-viewreview-power-point.(Online), rev. 8 Mei 2017.

Neumann, Michelle M, Glenn Finger, dan David L. Neumann.(2016). A Conceptual Framework for Emergent Digital Literacy, in Early Childhood Educ, 123-133.

Nurudin. (2012). Dasar-Dasar Penulisan. Malang: UMM Press.

Olmanson, Justin etc. (2007). Visualizing Revision: Leveraging Student-Generated Between Draft Diagramming Data in Support of Academic Writing Development. USA: Springer.

Ortlieb, Evan, etc. (2017). Rethinking Writing Products and Processes in a Digital Age. Literacy Research, Practice, and Evaluation, Vol. 7, 1-17.

Paltridge, Brian. (2004). Academic Writing. Language Teaching, 37 (2), 87-105.

Perin, Dolores, Alla Keselman \& Melissa Monopoli. (2003). The Academic Writing of Community College Remedial Students: Text and Learner Variables. Netherlands: Kluwer Academic Publisher.

Robertson, Marla, Leslie Patterson, and Carol Wickstrom. (2017). Powerful Writing Instruction: Seeing, Understanding, and Influencing Patterns. Literacy Research, Practice, and Evaluation, Vol. 7, 241-261.

Rye, James, Rick Landenberger, Timothy A. Warner.(2013). Incorporating Concept ～Mapping in Project Based Learning: Lessons from Watershed Investigations. J. Sci Educ Technol, 22, 379-392.

Sanchez, Soraya Garcia dan Carmen Lujan-Garcia. (2015). M-Learning and U- Learning Environments to Enhance EFL Communicative Competence, in Handbook of Mobile Teaching and Learning. 1-15.

Sergio L. Toral marín, etc. (2006). Planning a Master's Level Curriculum According to Career Space Recommendations Using Concept Mapping Techniques. International Journal of Technology and Design Education. 16, 237-252.

Toral, S.L, M. R. Mart ^’nez-Torres, F. Barrero, S. Gallardo, dan M. J. Durán. (2007). An Electronic Engineering Curriculum Design Based on Concept-Mapping Techniques. Int J Technol Des Educ. Vol. 17, 341-356.

Wirtz, Jason. (2012). Writing Courses Live and Die by The Quality of Peer Review. Hunzer, in Kathleen M. (Ed) Collaborative Learning and Writing. Essays on Using Small Groups in Teaching English and Composition. North Carolina: McFarland \& Company.

Wu, Dan. (2013). Introducing Writing Across The Curriculum into China. Feasibility and Adaptation. London: Springer. 